\title{
Impact of Serum Progesterone Levels in GnRH Antagonist Assisted Reproduction Cycles on Pregnancy Outcomes: A Prospective Cohort Study
}

\author{
Ahmed Abdelaziz ${ }^{1,2}$ (ㅇ, Hytham Atia ${ }^{3,4}$ (1) \\ ${ }^{1}$ Obstetrics and Gynecology Department, Faculty of Medicine, Ain-Shams University, Cairo, Egypt \\ ${ }^{2}$ Armed Forces Hospital North-Western Region, Tabuk, Saudi Arabia \\ ${ }^{3}$ Obstetrics and Gynecology Department, King Faisal Military Hospital, Khamis Mushait, Saudi Arabia \\ ${ }^{4}$ Obstetrics and Gynecology Department, Zagazig University, Zagazig, Egypt \\ Email:dr.aaziz@hotmail.com, hythamatia@gmail.com
}

How to cite this paper: Abdelaziz, A. and Atia, H. (2019) Impact of Serum Progesterone Levels in GnRH Antagonist Assisted Reproduction Cycles on Pregnancy Outcomes: A Prospective Cohort Study. Open Journal of Obstetrics and Gynecology, 9, 42-53.

https://doi.org/10.4236/ojog.2019.91005

Received: December 14, 2018

Accepted: January 11, 2019

Published: January 14, 2019

Copyright $\odot 2019$ by author(s) and Scientific Research Publishing Inc. This work is licensed under the Creative Commons Attribution International License (CC BY 4.0).

http://creativecommons.org/licenses/by/4.0/

(c) (i) Open Access

\begin{abstract}
Background: With controlled ovarian hyperstimulation $(\mathrm{COH})$ with gonadotrophin releasing hormone $(\mathrm{GnRH})$ antagonists, sometimes it is associated with incomplete luteolysis leading to elevated serum progesterone in early follicular phase. Persistence of this elevation might reduce the chance for clinical pregnancy. Objective: To assess the effect of elevated early and late follicular progesterone $(\mathrm{P})$ levels during gonadotrophins releasing hormone $(\mathrm{GnRH})$ antagonist cycles on pregnancy outcome. Design: Prospective single center study. Setting: North-western Military hospital, Kingdom of Saudi Arabia. Patients: 302 in vitro fertilization/intra-cytoplasmic sperm injection (IVF-ICSI) patients. Intervention(s): Recombinant follicle stimulating hormone (r-FSH), (150 - $300 \mathrm{IU})$ started daily from cycle day 2; GnRH antagonist treatment started on day 6 of the cycle. The serum progesterone $(\mathrm{P})$ measured twice on cycle day 2 and human chorionic gonadotrophin (hCG) day. Main Outcome Measures: Clinical pregnancy and live birth rates per started cycle. Results: The incidence of elevated serum P on day 2 was (5.3\%) and on hCG day was (17.5\%), statistically significant differences in clinical pregnancy rate $(32.3 \%$ versus $13.0 \%)$ and in live birth rate $(23.4 \%$ versus $11.1 \%)$ were present between the normal and high serum progesterone groups on hCG day, but these differences were not statistically significant in the groups of elevated basal progesterone. Conclusion: Follicular phase progesterone rise either on day 2 or the day of hCG trigger was associated with lower clinical pregnancy and live birth rates. This impact was more prominent with trigger day elevation.
\end{abstract}




\section{Keywords}

Elevated Progesterone, Clinical Pregnancy Rate, Live Birth Rate, GnRH Antagonist Cycles, IVF/ICSI

\section{Introduction}

The usage of controlled ovarian stimulation created the necessity for continuous research efforts to adjust the physiological performance of the stimulated cycle and increase the chance for pregnancy after intra-cytoplasmic sperm injection (ICSI) cycles. The cellular and molecular impacts of progesterone rise on the human chorionic gonadotrophin (hCG) trigger day and consequently reproductive outcomes are of these concerns [1] [2].

With controlled ovarian hyperstimulation $(\mathrm{COH})$ with gonadotrophin releasing hormone $(\mathrm{GnRH})$ antagonists, sometimes it is associated with incomplete luteolysis leading to elevated serum progesterone in early follicular phase [3] [4]. If the elevated progesterone levels persisted or for any other reasons became high pre-ovulatory, this might reduce the chance for clinical pregnancy. Some studies confirmed in their findings the detrimental impact of this elevation [5] [6] [7], while others failed to appreciate this negative effect [8]. Third group confirmed the negative effect for cases with reduced or normal ovarian response for induction, while high responders were exempted from that effect [1] [4] [9].

Most of the concerned studies neglected other peri-ovulatory parameters like number of retrieved follicles, oocyte maturation and endometrial thickness and receptivity that might modify the outcome and act as confounders for the real impact of elevated serum progesterone on the clinical pregnancy and live birth rates [10] [11] [12].

We aimed to study the impact of elevated basal serum progesterone and at the time of ovulation triggering by hCG on the success of achieving clinical pregnancy, in patients receiving controlled ovarian hyperstimulation with $\mathrm{GnRH}$ antagonist with normal response and in the light of other possible confounders.

\section{Methodology}

The current research is a single-center prospective cohort study of 302 cases underwent ICSI antagonist cycles, conducted at North-Western Armed Forces Hospital, Kingdom of Saudi Arabia. Recruitment of cases started from January 2015 till January 2018. Ovarian stimulation was carried out using only recombi-

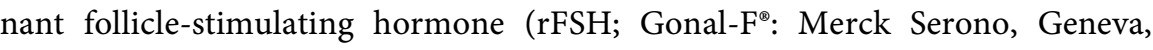
Switzerland). Gonadotrophins were initiated on day 2 of the cycle. Doses varied from 150 to $300 \mathrm{IU} /$ day subcutaneous injections, according to patient's age, body mass index (BMI), menstrual cycle characteristics, profile of basal hormones, and response to previous $\mathrm{COH}$. Follicular growth was evaluated by vaginal sonography. A daily dosage of $0.25 \mathrm{mg}$ of $\mathrm{GnRH}$ antagonist (Cetrorelix ${ }^{\circledast}$; Cetrotide: 
MerckSerono, Geneva, Switzerland) subcutaneous administration was started on day 6 of the cycle and sustained till the day of hCG trigger. Oocyte maturation was initiated by subcutaneous administration of hCG (rhCG; Ovidrel ${ }^{\oplus}: 250 \mathrm{mi}$ crograms Merck Serono, Geneva, Switzerland) when at least one follicle had a mean diameter of $18 \mathrm{~mm}$ and two had a mean diameter of $16 \mathrm{~mm}$. Transvaginal sonographic guided oocyte retrieval was performed 34 to 36 hours after trigger. Number of replaced embryos ( 1 - 3 embryos) depended on the patient age, developmental stage and quality of the embryos and previous IVF cycle outcome [2]. Luteal phase support began on oocyte retrieval day and was composed of vaginal progesterone applied intravaginally, in two separate doses (Crinone 8\% gel; Merck Serono, Geneva, Switzerland ), and was continued till performance of the serum B-hCG assay and, if positive, it was maintained till the $12^{\text {th }}$ gestational week.

All 302 cycles have been categorized in accordance to their progesterone serum levels at the start of COHand on hCG trigger day by usage of cutoff value of $1.5 \mathrm{ng} / \mathrm{ml}$. Four research groups:

- Group A: cases with both basal progesterone and on hCG day $\leq 1.5 \mathrm{ng} / \mathrm{ml}$.

- Group B: cases with basal progesterone $\leq 1.5 \mathrm{ng} / \mathrm{ml}$ and $>1.5 \mathrm{ng} / \mathrm{ml}$ on hCG day.

- Group C: cases with basal progesterone $>1.5 \mathrm{ng} / \mathrm{ml}$ and $\leq 1.5 \mathrm{ng} / \mathrm{ml}$ on hCG day.

- Group D: cases with both basal progesterone and on hCG day $>1.5 \mathrm{ng} / \mathrm{ml}$.

- These groups were reassigned into two main groups according to basal serum progesterone then its level on the hCG trigger day either below or more than $1.5 \mathrm{ng} / \mathrm{ml}$.

\subsection{Hormonal Measurement}

Early in the follicular phase of GnRH antagonist cycle, serum estradiol (E2), progesterone, luteinizing hormone (LH) and follicle stimulating hormone (FSH) were measured on the second day of cycle, which was the day of initiation of therapy. Serum progesterone and estradiol were repeated on the day of triggering of ovulation by hCG. The result of progesterone did not affect the decision for hCG administration.

\subsection{Primary Outcomes}

Clinical pregnancy and live birth rates. Clinical pregnancy is defined by sonographic gestational sac visualization at 6 weeks of gestation with presence of embryonic heart beat on ultrasound. Live birth is birth beyond 24 weeks with any sign of life [13].

\subsection{Secondary Outcomes}

The dosage and duration of gonadotrophin administered; endometrial lining thickness, number of oocytes retrieved, number of metaphase II (M II) oocytes, rates of fertilization and cleavage, and available number of embryos.

All cases recruited have signed an informed written consent to allow usage of 
their medical data for scientific research, before beginning their own management cycles. Ethical approval was obtained from the local institutional research board of the hospital.

\subsection{Sample Size}

We used $G^{\star}$ Power software (version 3.1.9.2, Heinrich-Heine-Universitat, Dusseldorf, Germany) to calculate the sample size. We calculated the required sample size sufficient for detection of difference between cases with low and high progesterone regarding clinical pregnancy and live birth rates with effect size $\mathrm{d}$ 0.5 , a error $0.05 \%$ and power $90 \%$. Least required sample size was 172 cases.

\subsection{Statistical Methods}

Statistical analysis was performed using SPSS version 21 [IBM Corp., Armonk, NY]. Shapiro-Wilk test was used to examine the numerical data for normality of distribution. Normally distributed data were presented as mean \pm standard deviation (SD) and in-between groups' differences were calculated using independent samples t-test and one-way ANOVA test as appropriate, Game-Howel post hoc test to estimate significance in-between groups. Categorical data were presented as number and percentage (\%) and in-between groups' differences were calculated using Chi-squared test or Fisher's exact test as appropriate. Multivariable binary logistic regression was used to determine independent predictors for successful clinical pregnancy and live birth. All the potential factors were adjusted for, including: basal progesterone, FSH, number of follicles, trigger day progesterone, number of oocytes retrieved, oocyte maturation and fertilization and endometrial thickness. The "enter" method was used to force all explanatory variables into the model.

\section{Results}

At the end of study period, data of 302 participants were statistically analyzed. Cases with both basal progesterone and on hCG day $\leq 1.5 \mathrm{ng} / \mathrm{ml}$ (group A), cases with basal progesterone $\leq 1.5 \mathrm{ng} / \mathrm{ml}$ and $>1.5 \mathrm{ng} / \mathrm{ml}$ on hCG day (group B), cases with basal progesterone $>1.5 \mathrm{ng} / \mathrm{ml}$ and $\leq 1.5 \mathrm{ng} / \mathrm{ml}$ on hCG day (group C) and cases with both basal progesterone and on hCG day $>1.5 \mathrm{ng} / \mathrm{ml}$ (group D). All groups were comparable in demographic criteria including age, body mass index (BMI), parity and infertility duration. No statistically significant difference in basal FSH and estradiol serum levels, stimulation duration and endometrial thickness on the day of embryo transfer. While the differences were statistically significant between groups in basal progesterone, progesterone level on trigger day, the total amount of gonadotrophins used to accomplish ovarian hyperstimulation and the number of follicles on hCG day (Table 1).

According to basal serum progesterone levels then at the day of hCG triggering of ovulation, these four groups were coalesced into two main groups with the cutoff $1.5 \mathrm{ng} / \mathrm{ml}$ to study the outcome of ovarian stimulation, fertilization and embryo transfer for normal responders [1]. Cases with higher basal serum 
Table 1. Baseline and stimulation parameters among the studied groups.

\begin{tabular}{|c|c|c|c|c|c|}
\hline Variables & $\begin{array}{l}\text { Group } A^{a} \\
(n=239)\end{array}$ & $\begin{array}{c}\text { Group } B^{b} \\
(n=47)\end{array}$ & $\begin{array}{l}\text { Group } C^{c} \\
(n=9)\end{array}$ & $\begin{array}{c}\text { Group } D^{d} \\
(n=7)\end{array}$ & $P$ value \\
\hline Age (years) $($ mean $\pm S D)$ & $25.8 \pm 2.5$ & $26.1 \pm 2.9$ & $26.2 \pm 2.8$ & $26.6 \pm 3.2$ & 0.833 \\
\hline BMI $\left(\mathrm{kg} / \mathrm{m}^{2}\right)($ mean $\pm \mathrm{SD})$ & $25.4 \pm 1.4$ & $25.5 \pm 1.5$ & $25.5 \pm 1.3$ & $24.7 \pm 1.5$ & 0.722 \\
\hline Parity & $1(0-1)$ & $1(0-1)$ & $1(0-1)$ & $0(0-1)$ & 0.678 \\
\hline $\begin{array}{l}\text { Infertility duration (years) } \\
\text { (mean } \pm \mathrm{SD})\end{array}$ & $3.9 \pm 1.6$ & $4.1 \pm 1.8$ & $4.2 \pm 1.9$ & $4.4 \pm 2.7$ & 0.815 \\
\hline $\mathrm{FSH}(\mathrm{IU} / \mathrm{mL})($ mean $\pm \mathrm{SD})$ & $6.3 \pm 1.9$ & $5.8 \pm 1.9$ & $6.7 \pm 2.7$ & $5.5 \pm 2.2$ & 0.320 \\
\hline $\begin{array}{l}\text { Basal Estradiol }(\mathrm{pg} / \mathrm{mL}) \\
(\text { mean } \pm \mathrm{SD})\end{array}$ & $71.4 \pm 16.1$ & $70.7 \pm 11.9$ & $68.8 \pm 14.0$ & $63.8 \pm 19.8$ & 0.702 \\
\hline $\begin{array}{l}\text { Basal progesterone }(\mathrm{ng} / \mathrm{mL}) \\
(\text { mean } \pm \mathrm{SD})\end{array}$ & $0.66 \pm 0.15$ & $0.84 \pm 0.18$ & $1.77 \pm 0.16$ & $1.78 \pm 0.18$ & $0.000^{*}$ \\
\hline $\begin{array}{l}\text { Progesterone on hCG day }(\mathrm{ng} / \mathrm{mL}) \\
(\text { mean } \pm \text { SD) }\end{array}$ & $0.64 \pm 0.15$ & $1.88 \pm 0.15$ & $1.02 \pm 0.25$ & $1.99 \pm 0.51$ & $0.000^{*}$ \\
\hline $\begin{array}{l}\text { No. of follicles on hCG day } \\
\text { (mean } \pm \text { SD) }\end{array}$ & $5.67 \pm 2.15$ & $7.31 \pm 1.35$ & $5.24 \pm 1.58$ & $7.62 \pm 1.71$ & $0.001^{*}$ \\
\hline $\begin{array}{l}\text { Total gonadotrophins (IU) } \\
\text { (mean } \pm \text { SD) }\end{array}$ & $2077 \pm 164$ & $2208 \pm 177$ & $2235 \pm 171$ & $2421 \pm 124$ & $0.000^{*}$ \\
\hline $\begin{array}{l}\text { Duration of stimulation (days) } \\
\text { (mean } \pm \mathrm{SD} \text { ) }\end{array}$ & $9.98 \pm 0.95$ & $9.87 \pm 0.80$ & $9.78 \pm 0.83$ & $10.43 \pm 0.53$ & 0.482 \\
\hline $\begin{array}{l}\text { Endometrial thickness ET day } \\
(\mathrm{mm})(\text { mean } \pm \mathrm{SD})\end{array}$ & $10.28 \pm 1.18$ & $10.41 \pm 1.10$ & $10.33 \pm 0.50$ & $9.71 \pm 0.75$ & 0.440 \\
\hline
\end{tabular}

${ }^{\mathrm{a}}$ Group A: cases with both basal progesterone and on hCG day $\leq 1.5 \mathrm{ng} / \mathrm{ml}$. ${ }^{\mathrm{b}}$ Group B' cases with basal progesterone $\leq 1.5 \mathrm{ng} / \mathrm{ml}$ and $>1.5 \mathrm{ng} / \mathrm{ml}$ on $\mathrm{hCG}$ day. ${ }^{\mathrm{c}} \mathrm{Group} \mathrm{C}^{\mathrm{C}}$ cases with basal progesterone $>1.5 \mathrm{ng} / \mathrm{ml}$ and $\leq 1.5 \mathrm{ng} / \mathrm{ml}$ on hCG day. ${ }^{\mathrm{d}}$ Group D' cases with both basal progesterone and on hCG day $>1.5 \mathrm{ng} / \mathrm{ml}$. ${ }^{\star}$ Statistically significant result. BMI: body mass index; FSH: follicle stimulating hormone; ET: embryo transfer.

progesterone had higher number of total and MII oocytes retrieved (13.63 versus $11.54,7.83$ versus 6.65 respectively). Inversely, they had statistically significant lower fertilization rate $(59.1 \%$ versus $63.6 \%)$ and insignificant lower embryo cleavage, clinical pregnancy and live birth rates compared to women with lower basal serum progesterone (91.8\% versus $97.4 \%, 18.8 \%$ versus $29.4 \%$ and $18.8 \%$ versus $21.3 \%$ respectively) (Table 2 ).

Despite cases with trigger day progesterone levels above the defined cutoff produced higher number of retrieved oocytes; the maturation, fertilization and embryo cleavage rates were significantly lower than in cases with lower progesterone levels (56.5\% versus $63.6 \%$, $59.3 \%$ versus $66.5 \%$ and $92.5 \%$ versus $98.2 \%$ respectively). This was implicated by significantly lower clinical pregnancy and live birth rates in high progesterone on hCG trigger day group (13\% versus $32.3 \%$ and $11.1 \%$ versus $23.4 \%$ respectively) (Table 3 ).

Among the different studied ovulation induction variables of multivariable binary logistic regression model, despite progesterone level on day of ovulation trigger was the strongest independent reverse predictor [regression coefficient (B) $=-4.915]$ of clinical pregnancy occurrence, it was not the only predictor. 
Table 2. Outcome of ovarian stimulation, fertilization and embryo transfer between cases with basal serum progesterone $\leq 1.5 \mathrm{ng} / \mathrm{ml}$ and those with $>1.5 \mathrm{ng} / \mathrm{ml}$.

\begin{tabular}{cccc}
\hline & $\begin{array}{c}\text { Basal progesterone } \\
\leq 1.5 \mathrm{ng} / \mathrm{ml} \text { (n=268) }\end{array}$ & $\begin{array}{c}\text { Basal progesterone } \\
>1.5 \mathrm{ng} / \mathrm{ml}(\mathrm{n}=16)\end{array}$ & P value \\
\hline $\begin{array}{c}\text { Retrieved oocytes No. } \\
11.54 \pm 2.23\end{array}$ & $13.63 \pm 2.31$ & $0.000^{*}$ \\
$\begin{array}{c}\text { Retrieved M II oocytes No. } \\
\text { Maturation rate \% }\end{array}$ & $6.65 \pm 1.55$ & $7.83 \pm 1.97$ & $0.010^{*}$ \\
$\begin{array}{c}\text { (M II/oocytes retrieved) } \\
\text { Fertilized oocytes No. }\end{array}$ & $57.6 \pm 14.1$ & $57.4 \pm 14.0$ & 0.281 \\
$\begin{array}{c}\text { Fertilization rate \% } \\
\text { (Fertilized/ M II retrieved) }\end{array}$ & $6.23 \pm 0.69$ & $4.63 \pm 1.27$ & 0.545 \\
$\begin{array}{c}\text { Cleaved embryos No. } \\
\text { Embryos cleavage rate \% } \\
\text { (Cleaved/fertilized) }\end{array}$ & $4.12 \pm 0.66$ & $59.1 \pm 17.9$ & 0.046 \\
Clinical pregnancy (\%) & $97.4 \pm 0.6$ & $4.25 \pm 1.15$ & 0.717 \\
$\quad$ Live birth (\%) & $84(29.4 \%)$ & $91.8 \pm 1.3$ & 0.371 \\
\hline
\end{tabular}

*Statistically significant result.

Table 3. Outcome of ovarian stimulation, fertilization and embryo transfer between cases with serum progesterone $\leq 1.5 \mathrm{ng} / \mathrm{ml}$ and those with $>1.5 \mathrm{ng} / \mathrm{ml}$ on hCG day.

\begin{tabular}{cccc}
\hline & $\begin{array}{c}\text { Progesterone on hCG day } \\
\leq 1.5 \mathrm{ng} / \mathrm{ml}(\mathrm{n}=\mathbf{2 4 8})\end{array}$ & $\begin{array}{c}\text { Progesterone on hCG day } \\
>1.5 \mathrm{ng} / \mathrm{ml}(\mathrm{n}=\mathbf{5 4})\end{array}$ & P value \\
\hline $\begin{array}{c}\text { Retrieved oocytes No. } \\
\text { Retrieved M II oocytes No. }\end{array}$ & $6.86 \pm 1.51$ & $15.81 \pm 1.56$ & $0.000^{*}$ \\
$\begin{array}{c}\text { Maturation rate \% } \\
\text { (M II/oocytes retrieved) }\end{array}$ & $63.6 \pm 14.1$ & $8.93 \pm 2.57$ & $0.000^{*}$ \\
$\begin{array}{c}\text { Fertilized oocytes No. } \\
\text { Fertilization rate \% }\end{array}$ & $4.56 \pm 0.69$ & $56.5 \pm 14.0$ & $0.000^{*}$ \\
$\begin{array}{c}\text { (Fertilized/M II retrieved) } \\
\text { Cleaved embryos No. }\end{array}$ & $66.5 \pm 14.1$ & $5.29 \pm 1.27$ & $0.000^{*}$ \\
$\begin{array}{c}\text { Embryos cleavage rate \% } \\
\text { (Cleaved/fertilized) }\end{array}$ & $4.48 \pm 0.66$ & $59.3 \pm 17.9$ & $0.002^{*}$ \\
Clinical pregnancy (\%) & $98.2 \pm 0.7$ & $4.89 \pm 1.15$ & $0.000^{*}$ \\
$\quad$ Live birth (\%) & $80(32.3 \%)$ & $92.5 \pm 1.6$ & $0.000^{*}$ \\
\hline
\end{tabular}

*Statistically significant result.

The number of follicles on day of hCG trigger, endometrial thickness on day of embryo transfer and total number of retrieved and M II oocytes were also significant independent predictors for clinical pregnancy occurrence in the study group [ $\mathrm{B}=-1.502,-1.073,0.979$ and 0.966 respectively]. The same variables were significant predictors for live birth $[\mathrm{B}=-0.995,-0.419,0.417$ and 0.412 respectively] beside the trigger day progesterone $[\mathrm{B}=-1.961]$. These can function as modifiers of the real impact of high trigger day serum progesterone on clinical pregnancy and live birth rates (Table $4 \&$ Table 5). 
Table 4. Multivariable binary logistic regression model showing different parameters as independent predictors for occurrence of clinical pregnancy.

\begin{tabular}{cccccc}
\hline Covariate & B & SE & OR & $95 \%$ CI & P \\
\hline Basal progesterone & -0.123 & 0.734 & 0.867 & $0.210-3.730$ & 0.867 \\
Progesterone on hCG day & -4.915 & 0.998 & 0.007 & $0.001-0.052$ & $0.000^{*}$ \\
No. of follicles on hCG day & -1.502 & 0.238 & 0.222 & $0.139-0.354$ & $0.000^{*}$ \\
Endometrial thickness ET day & -1.073 & 0.224 & 0.342 & $0.221-0.530$ & $0.000^{*}$ \\
$\quad$ Retrieved oocytes No. & 0.979 & 0.219 & 2.66 & $1.732-4.088$ & $0.000^{*}$ \\
Retrieved M II oocytes No. & 0.966 & 0.232 & 2.627 & $1.668-4.138$ & $0.000^{*}$ \\
$\quad$ Fertilized oocytes No. & -0.620 & 0.425 & 0.538 & $0.234-1.238$ & 0.145 \\
Cleaved embryos No. & -0.484 & 0.466 & 0.299 & $0.247-1.536$ & 0.299 \\
\hline
\end{tabular}

95\% CI, 95\% confidence interval; B, regression coefficient; OR, odds ratio; SE, standard error. Hosmer and Lemeshow goodness of fit test was insignificant. $\chi^{2}(8, \mathrm{~N}=302)=150.69, \mathrm{P}<0.016 .36 .4 \%$ to $52.0 \%$ of the variance in the dependent variable can be explained by independent variables in the model. Percentage of accuracy (PAC) of the model is $78.8 \%$. Statistically significant result.

Table 5. Multivariable binary logistic regression model showing different parameters as independent predictors for occurrence of live birth.

\begin{tabular}{cccccc}
\hline Covariate & B & SE & OR & $95 \%$ CI & P \\
\hline Basal progesterone & 0.474 & 0.668 & 1.606 & $0.434-5.964$ & 0.478 \\
Progesterone on hCG day & -1.961 & 0.770 & 0.141 & $0.031-0.636$ & $0.011^{*}$ \\
$\begin{array}{c}\text { No. of follicles on hCG day } \\
\text { Endometrial thickness ET day }\end{array}$ & -0.995 & 0.195 & 0.370 & $0.252-0.542$ & $0.023^{*}$ \\
$\quad-0.419$ & 0.166 & 0.658 & $0.475-0.910$ & $0.019^{*}$ \\
$\quad \begin{array}{c}\text { Retrieved oocytes No. } \\
\text { Retrieved M II oocytes No. }\end{array}$ & 0.417 & 0.184 & 1.517 & $1.058-2.150$ & $0.024^{*}$ \\
$\quad 0.412$ & 0.180 & 1.510 & $1.060-2.150$ & $0.022^{*}$ \\
Fertilized oocytes No. & -0.574 & 0.425 & 0.564 & $0.245-1.295$ & 0.177 \\
Cleaved embryos No. & -0.234 & 0.464 & 0.792 & $0.319-1.966$ & 0.615 \\
\hline
\end{tabular}

95\% CI, 95\% confidence interval; B, regression coefficient; OR, odds ratio; SE, standard error. Hosmer and Lemeshow goodness of fit test was insignificant. $\chi^{2}(8, \mathrm{~N}=302)=61.842, \mathrm{P}<0.001 .18 .5 \%$ to $28.8 \%$ of the variance in the dependent variable can be explained by independent variables in the model. Percentage of accuracy (PAC) of the model is $78.8 \%$. Statistically significant result.

\section{Discussion}

Follicular phase progesterone rise affects $12.3 \%$ to $46.7 \%$ of the fresh IVF-ICSI cycles depending on the progesterone cut-off value used. This wide variation may be attributed to the type of stimulation protocol, gonadotrophins used and patients' characteristics such as age, body mass index, ethnicity, ovarian response and history of recurrent IVF failure [14] [15] [16].

In our study, elevated basal serum progesterone was associated with higher number of retrieved oocytes and metaphase II oocytes in comparison to group with normal serum progesterone (13.63 \pm 2.31 versus $11.54 \pm 2.23$ oocytes and $7.83 \pm 1.97$ versus $6.65 \pm 1.55$ oocytes respectively). However, the fertilization, clinical pregnancy and live birth rates were higher in normal basal progesterone 
group in comparison to high basal progesterone group (63.6\% versus $59.1 \%$, $29.4 \%$ versus $18.8 \%$ and $21.3 \%$ versus $18.8 \%$ respectively). However, these differences were statistically insignificant except for fertilization rate. This may be explained by the small number of the studied groups and it needs further confirmation in prospective studies with a larger number of patients. This study results go with study of Kolibianakis et al. [17] who delayed start of ovarian hyperstimulation till normalization of early follicular progesterone in the group of patients who have elevated levels on day 2 of the cycle; however, still this group of patients had statistically significant lower ongoing pregnancy rate per started cycle $(5.0 \%$ versus $31.8 \%, \mathrm{P}=0.01)$ and per embryo transfer $(6.3 \%$ versus $36.9 \%, \mathrm{P}=0.01$ ) compared with the normal group. In another study by Blockeel et al. [18] who used antagonist for 3 days in a group of patients with elevated early follicular progesterone to normalize serum progesterone before controlled ovarian hyperstimulation, pregnancy rate did not differ in both groups. However, a trend of lower ongoing pregnancy rates was found in the high progesterone group. In the study done by Hamdine et al. [4] incorporating their results with the above mentioned studies, their meta-analysis showed that the chance of achieving ongoing pregnancy decreases by $15 \%$ if serum progesterone was high in early follicular phase in GnRH antagonist cycle. In view of available evidence, elevated serum progesterone in follicular phase may be a contributing factor to lower clinical pregnancy and live birth rates.

In this study elevation of serum progesterone on day of hCG trigger was associated with higher number of retrieved oocytes $(15.81 \pm 1.56$ versus $10.79 \pm 1.23$ oocytes) and metaphase II oocytes ( $8.93 \pm 2.57$ versus $6.86 \pm 1.51$ oocytes $)$ compared to the group with normal serum progesterone on day of trigger. However, maturation and fertilization rates were higher in group with normal serum progesterone on day of trigger when compared to the group with the elevated serum progesterone (63.6\% versus $56.5 \%$ and $66.5 \%$ versus $59.3 \%$ respectively). These differences in outcomes between both groups continued to be in favor of normal serum progesterone in embryo cleavage rate (98.2\% versus $92.5 \%)$, clinical pregnancy rate $(32.3 \%$ versus $13.0 \%)$ and live birth rate $(23.4 \%$ versus $11.1 \%)$ compared to elevated progesterone group on day of trigger. The lower clinical pregnancy and live birth rates in group with high basal or late follicular progesterone may be explained by its effect on endometrium (altered receptivity) or its effect on oocyte/embryo quality or the synchrony between the two (advancement of implantation window) [19].

The present literature presents conflicting evidence on its effect on oocyte and embryo quality. While some studies demonstrated an adverse effect on oocyte and top quality embryos rates [20] [21] [22] [23], others showed comparable oocyte quality, fertilization, cleavage rates and embryo quality between high and normal progesterone groups [9] [24]-[29]. When it comes to clinical pregnancy and live birth rates, the dilemma continues. Some reports showed evidence of improved outcome [30] [31], while others concluded no significant effect [32] 
[33] [34] [35] or even unfavorable effects [1] [36] [37] [38]. These differences in literature arise due to different cut off values of progesterone used as threshold, different days of serum progesterone measurement and different measurement methods with different sensitivity of the kits used. The issue of follicular phase progesterone rise and its impact on reproductive outcomes in assisted reproduction techniques cycles are more complex than was initially thought and standardization of the above mentioned factors in adequately powered trials adopting personalized approach for each patient might highlight the best approach and plan for those cycles with follicular phase progesterone rise.

The limitations of the current study are small sample size and lack of intervention for those with progesterone rise either on day 2 or hCG trigger day, while strength is selecting clinical pregnancy and live birth rates as the primary outcome points.

\section{Conclusion}

Follicular phase progesterone rise either on day 2 or the day of hCG trigger was associated with lower clinical pregnancy and live birth rates. This impact was more prominent with the trigger day elevation. Further strong prospective studies are required to probe the best management for cycles showing this elevation.

\section{Conflicts of Interest}

The authors declare no conflicts of interest regarding the publication of this paper.

\section{References}

[1] Griesinger, G., Mannaerts, B., Andersen, C.Y., Witjes, H., Kolibianakis, E.M. and Gordon, K. (2013) Progesterone Elevation Does Not Compromise Pregnancy Rates in High Responders: A Pooled Analysis of in Vitro Fertilization Patients Treated with Recombinant Follicle-Stimulating Hormone/Gonadotropin-Releasing Hormone Antagonist in Six Trials. Fertility and Sterility, 100, 1622-1628.e3. https://doi.org/10.1016/j.fertnstert.2013.08.045

[2] Venetis, C.A., Kolibianakis, E.M., Bosdou, J.K., et al. (2015) Estimating the Net Effect of Progesterone Elevation on the Day of hCG on Live Birth Rates after IVF: A Cohort Analysis of 3296 IVF Cycles. Human Reproduction, 30, 684-691. https://doi.org/10.1093/humrep/deu362

[3] Panaino, T.R., da Silva, J.B., de Lima, M.A.T., et al. (2017) High Progesterone Levels in the Beginning of ICSI Antagonist Cycles and Clinical Pregnancy: Still a Concern? JBRA Assisted Reproduction, 21, 11-14.

[4] Hamdine, O., Macklon, N.S., Eijkemans, M.J.C., et al. (2014) Elevated Early Follicular Progesterone Levels and in Vitro Fertilization Outcomes: A Prospective Intervention Study and Meta-Analysis. Fertility and Sterility, 102, 448-454.e1. https://doi.org/10.1016/j.fertnstert.2014.05.002

[5] Santos-Ribeiro, S., Polyzos, N.P., Haentjens, P., et al. (2014) Live Birth Rates after IVF Are Reduced by Both Low and High Progesterone Levels on the Day of Human Chorionic Gonadotrophin Administration. Human Reproduction, 29, 1698-1705. 
https://doi.org/10.1093/humrep/deu151

[6] Xiong, Y., Wang, J., Liu, L., et al. (2017) Effects of High Progesterone Level on the Day of Human Chorionic Gonadotrophin Administration in in Vitro Fertilization Cycles on Epigenetic Modification of Endometrium in the Peri-Implantation Period. Fertility and Sterility, 108, 269-276.e1.

https://doi.org/10.1016/j.fertnstert.2017.06.004

[7] Venetis, C.A., Kolibianakis, E.M., Bosdou, J.K., et al. (2016) Basal Serum Progesterone and History of Elevated Progesterone on the Day of hCG Administration Are Significant Predictors of Late Follicular Progesterone Elevation in GnRH Antagonist IVF Cycles. Human Reproduction, 31, 1859-1865.

https://doi.org/10.1093/humrep/dew141

[8] Requena, A., Cruz, M., Bosch, E., Meseguer, M. and García-Velasco, J.A. (2014) High Progesterone Levels in Women with High Ovarian Response Do Not Affect Clinical Outcomes: A Retrospective Cohort Study. Reproductive Biology and Endocrinology, 12, 69. https://doi.org/10.1186/1477-7827-12-69

[9] Xu, B., Li, Z., Zhang, H., et al. (2012) Serum Progesterone Level Effects on the Outcome of in Vitro Fertilization in Patients with Different Ovarian Response: An Analysis of More than 10,000 Cycles. Fertility and Sterility, 97, 1321-1327.e4 https://doi.org/10.1016/j.fertnstert.2012.03.014

[10] Racca, A., Santos-Ribeiro, S., De Munck, N., et al. (2018) Impact of Late-Follicular Phase Elevated Serum Progesterone on Cumulative Live Birth Rates: Is There a Deleterious Effect on Embryo Quality? Human Reproduction, 33, 860-868. https://doi.org/10.1093/humrep/dey031

[11] Vanni, V.S., Somigliana, E., Reschini, M., et al. (2017) Top Quality Blastocyst Formation Rates in Relation to Progesterone Levels on the Day of Oocyte Maturation in GnRH Antagonist IVF/ICSI Cycles. PLoS One, 12, e0176482. https://doi.org/10.1371/journal.pone.0176482

[12] Lawrenz, B. and Fatemi, H.M. (2017) Effect of Progesterone Elevation in Follicular Phase of IVF-Cycles on the Endometrial Receptivity. Reproductive BioMedicine Online, 34, 422-428. https://doi.org/10.1016/j.rbmo.2017.01.011

[13] Martins, W.P., Niederberger, C., Nastri, C.O. and Racowsky, C. (2018) Making Evidence-Based Decisions in Reproductive Medicine. Fertility and Sterility, 110, 1227-1230. https://doi.org/10.1016/j.fertnstert.2018.08.010

[14] Schoolcraft, W., Sinton, E., Schlenker, T., Huynh, D., Hamilton, F. and Meldrum, D.R. (1991) Lower Pregnancy Rate with Premature Luteinization during Pituitary Suppression with Leuprolide Acetate. Fertility and Sterility, 55, 563-566.

[15] Liu, L., Zhou, F., Lin, X., et al. (2013) Recurrent IVF Failure Is Associated with Elevated Progesterone on the Day of hCG Administration. European Journal of Obstetrics Gynecology and Reproductive Biology, 171, 78-83.

https://doi.org/10.1016/j.ejogrb.2013.08.025

[16] Seow, K.M., Lin, Y.H., Hsieh, B.C., et al. (2010) Characteristics of Progesterone Changes in Women with Subtle Progesterone Rise in Recombinant Follicle-Stimulating Hormone and Gonadotropin-Releasing Hormone Antagonist Cycle. Gynecologic and Obstetric Investigation, 70, 64-68. https://doi.org/10.1159/000290062

[17] Kolibianakis, E.M., Zikopoulos, K., Smitz, J., et al. (2004) Elevated Progesterone at Initiation of Stimulation Is Associated with a Lower Ongoing Pregnancy Rate after IVF Using GnRH Antagonists. Human Reproduction, 19, 1525-1529. https://doi.org/10.1093/humrep/deh272 
[18] Blockeel, C., Baumgarten, M., de Vos, M., Verheyen, G. and Devroey, P. (2011) Administration of GnRH Antagonists in Case of Elevated Progesterone at Initiation of the Cycle: A Prospective Cohort Study. Current Pharmaceutical Biotechnology, 12, 423-428. https://doi.org/10.2174/138920111794480633

[19] Kaponis, A., Chronopoulou, E. and Decavalas, G. (2018) The Curious Case of Premature Luteinization. Journal of Assisted Reproduction and Genetics, 35, 1723-1740. https://doi.org/10.1007/s10815-018-1264-8

[20] Harada, T., Toda, T., Katagiri, C., Mio, Y., Takao, N. and Terakawa, N. (1996) Altering the Timing of Human Chorionic Gonadotropin Injection According to Serum Progesterone (P) Concentrations Improves Embryo Quality in Cycles with Subtle P Rise. Fertility and Sterility, 65, 594-597. https://doi.org/10.1016/S0015-0282(16)58160-6

[21] Harada, T., Yoshida, S., Katagiri, C., et al. (1995) Endocrinology: Reduced Implantation Rate Associated with a Subtle Rise in Serum Progesterone Concentration during the Follicular Phase of Cycles Stimulated with a Combination of a Gonadotrophin-Releasing Hormone Agonist and Gonadotrophin. Human Reproduction, 10, 1060-1064. https://doi.org/10.1093/oxfordjournals.humrep.a136094

[22] Bu, Z., Zhao, F., Wang, K., et al. (2014) Serum Progesterone Elevation Adversely Affects Cumulative Live birth Rate in Different Ovarian Responders during in Vitro Fertilization and Embryo Transfer: A Large Retrospective Study. PLoS ONE, 9, e100011. https://doi.org/10.1371/journal.pone.0100011

[23] Huang, B., Ren, X., Wu, L., et al. (2016) Elevated Progesterone Levels on the Day of Oocyte Maturation May Affect Top Quality Embryo IVF Cycles. PLoS ONE, 11, e0145895. https://doi.org/10.1371/journal.pone.0145895

[24] Melo, M.A.B., Meseguer, M., Garrido, N., Bosch, E., Pellicer, A. and Remohí, J. (2006) The Significance of Premature Luteinization in an Oocyte-Donation Programme. Human Reproduction, 21, 1503-1507. https://doi.org/10.1093/humrep/dei474

[25] Ubaldi, F., Smitz, J., Wisanto, A., et al. (1995) Oocyte and Embryo Quality as Well as Pregnancy Rate in Intracytoplasmic Sperm Injection Are Not Affected by High Follicular Phase Serum Progesterone. Human Reproduction, 10, 3091-3096. https://doi.org/10.1093/oxfordjournals.humrep.a135864

[26] Fanchin, R., De Ziegler, D., Taieb, J., Hazout, A. and Frydman, R. (1993) Premature Elevation of Plasma Progesterone Alters Pregnancy Rates of in Vitro Fertilization and Embryo Transfer. Fertility and Sterility, 59, 1090-1094. https://doi.org/10.1016/S0015-0282(16)55933-0

[27] Fanchin, R., Taieb, J., Hourvitz, A., Hazout, A., Olivennes, F. and Frydman, R. (1997) Premature Progesterone Elevation Spares Blastulation But Not Pregnancy Rates in in Vitro Fertilization with Coculture. Fertility and Sterility, 68, 648-652. https://doi.org/10.1016/S0015-0282(97)80464-5

[28] Corti, L., Papaleo, E., Pagliardini, L., et al. (2013) Fresh Blastocyst Transfer as a Clinical Approach to Overcome the Detrimental Effect of Progesterone Elevation at HCG Triggering: A Strategy in the Context of the Italian Law. European Journal of Obstetrics \& Gynecology and Reproductive Biology, 171, 73-77. https://doi.org/10.1016/j.ejogrb.2013.08.017

[29] Kiliçdag, E.B., Haydardedeoglu, B., Cok, T., Hacivelioglu, S.O. and Bagis, T. (2010) Premature Progesterone Elevation Impairs Implantation and Live Birth Rates in GnRH-Agonist IVF/ICSI Cycles. Archives of Gynecology and Obstetrics, 281, 747-752. https://doi.org/10.1007/s00404-009-1248-0 
[30] Peng, C., Guo, Z., Long, X. and Lu, G. (2012) Progesterone Levels on the hCG Day and Outcomes in Vitro Fertilization in Women with Polycystic Ovary Syndrome. Journal of Assisted Reproduction and Genetics, 29, 603-607. https://doi.org/10.1007/s10815-012-9762-6

[31] Ben-Nun, I., Ghetler, Y., Jaffe, R., Siegal, A., Kaneti, H. and Fejgin, M. (1990) Effect of Preovulatory Progesterone Administration on the Endometrial Maturation and Implantation Rate after in Vitro Fertilization and Embryo Transfer. Fertility and Sterility, 53, 276-281. https://doi.org/10.1016/S0015-0282(16)53281-6

[32] Martinez, F., Rodriguez, I., Devesa, M., Buxaderas, R., Gómez, M.J. and Coroleu, B. (2016) Should Progesterone on the Human Chorionic Gonadotropin Day Still Be Measured? Fertility and Sterility, 105, 86-92.

[33] Saharkhiz, N., Salehpour, S., Tavasoli, M. and Aghighi, A. (2015) Premature Progesterone Rise at Human Chorionic Gonadotropin Triggering Day Has No Correlation with Intracytoplasmic Sperm Injection Outcome. Iranian Journal of Reproductive Medicine, 13, 79-84.

[34] Acet, M., Aktün, L.H., Başaranoğlu, S., Yorgunlar, B., Acet, T. and Deregözü, A. (2015) Premature Progesterone Elevation Does Not Affect Pregnancy Outcome in High-Responder Patients Undergoing Short-Interval Coasting in IVF Cycles. Medical Science Monitor Basic Research, 21, 247-252.

https://doi.org/10.12659/MSMBR.896244

[35] Groenewoud, E.R., Macklon, N.S., Cohlen, B.J., et al. (2017) The Effect of Elevated Progesterone Levels before HCG Triggering in Modified Natural Cycle Frozen-Thawed Embryo Transfer Cycles. Reproductive BioMedicine Online, 34, 546-554. https://doi.org/10.1016/j.rbmo.2017.02.008

[36] Venetis, C.A., Kolibianakis, E.M., Bosdou, J.K. and Tarlatzis, B.C. (2013) Progesterone Elevation and Probability of Pregnancy after IVF: A Systematic Review and Meta-Analysis of over 60000 Cycles. Human Reproduction Update, 19, 433-457. https://doi.org/10.1093/humupd/dmt014

[37] Huang, Y., Wang, E.Y., Du, Q.Y., et al. (2015) Progesterone Elevation on the Day of Human Chorionic Gonadotropin Administration Adversely Affects the Outcome of IVF with Transferred Embryos at Different Developmental Stages. Reproductive Biology and Endocrinology, 13, 1-10. https://doi.org/10.1186/s12958-015-0075-3

[38] Koo, H.S., Cha, S.H., Kim, H.O., et al. (2015) A High Response to Controlled Ovarian Stimulation Induces Premature Luteinization with a Negative Impact on Pregnancy Outcomes in a Gonadotropin Releasing Hormone Antagonist Cycle. Clinical and Experimental Reproductive Medicine, 42, 149-155.

https://doi.org/10.5653/cerm.2015.42.4.149 